DE DE GRUYTER

OPEN
Journal of Intercultural Management

Vol. 7, No. 2, June 2015, pp. 89-111

DOI 10.1515/joim-2015-0012

Sylwia Przytuła ${ }^{28}$

Wroclaw University of Economics

\title{
Migrants, Assigned Expatriates (AE) and Self-initiated Expatriates (SIE) - Dfferentiation of Terms and Literature- Based Research Review
}

\begin{abstract}
The globalized world economy demand increasing global mobility and flexibility in the workplace and workforce. More and more skilled individuals seek international career opportunities. Thera are various mobile employees in the international context $[O E C D]$ among which are migrants, assigned expatriates (AE) and self-initiated expatriates (SIE).Many people experience international mobility through migration or as part of an expatriate assignment [Banai, Harry 2004; Capellen, Jansenss 2010; Dickman, Doherty 2010; Zikic et all 2010]. Yet an increasing number are choosing self-initiation expatriation [Bozionelos 2009; Selmer, Lauring 2010; Tharenou 2010; Doherty et all, 2013].

The purpose of this article is to enhance the conceptual coherence of the notion of migrant and assigned expatriate (AE) and self-initiated expatriate (SIE). Proposed definitions are based on a set of conceptual criteria which differentiates these three types of international movers.
\end{abstract}

Key words: migrant, assigned expatriate, self-initiated expatriate, transmigration

\section{Migration and mobility of international employees}

Migration, or spatial mobility is a relatively permanent change of residence making in geographic space [Kawczyńska-Butrym 2009, p. 11]. It can be defined as physical movement from one geographic point to another geographic point [Agozino 2000], crossing national borders [Boyle et all 1998]. Migration may be analysed from different perspectives: sociological and cultural, economic, legal and administrative, psychological and ethical. The literature on the subject specifies

\footnotetext{
${ }^{28}$ s_przytula@wp.pl
} 
several forms and classifications of migration depending on the assumed criterion of division: scope (internal and cross-border migration), duration (permanent, periodic, seasonal, shuttle), goal of relocation (economic, non-economic migration) and reasons for decision about migration (forced, voluntary migration) [KawczyńskaButrym 2009, p. 16].

Migrations, which are also called the movement by people, have been present from the very beginning ${ }^{29}$ although their intensity and forms have been different over the centuries and people have migrated for different reasons.

It is said that migration is a structural element of modern societies, highly developed economy, the world of free competition and civil liberties. Yet, is the migration actually something typical of this period in the history of mankind or does it only display only some specific features in these times that have been unknown or undiscovered thus far? After all, the economy and culture of the United States, Canada, New Zealand and the Republic of South Africa, Argentina or Chile were built by the immigrants looking for better living conditions. The population of Australia and Siberia, Brazil and the Caribbean is also the result of migration (which was often a forced one). The Arabic, English, Turkish or French languages spread because of military and cultural expansion which was characterised with the migration of large groups of people [Zięba 2008].

The map of global flows of workers has completely changed over the last 40 years. The first wave of international transfers occurred in the years 1970-1990 and they were the foreign assignments 'pulled' by international corporations whose headquarters were located - the most often - in the United States and their subsidiaries were established in other parts of the world. The next wave of relocations took place in the years 1990-2010. The new emerging markets attracted the financial capital as well as human capital to the developing countries that were interesting because of low costs of production and labour, resource prices, etc. On the other hand, the workers from those countries looked for the sources of knowledge and developed technology, and thus the transfers took place not only between the continents but also within the continents. Yet, in majority of cases, the flow of global talents and specialists was still a one-way one, that is from the West to the East. However, the corporations started to notice and use the resources of qualified employees in dynamically developing countries, e. g. in India. During the next decade, that is the years 2010-2020, the directions of employees' relocations has been multidirectional in vertical terms (that is from the North to the South and vice versa) and horizontal terms (from the East to the West and vice versa) [Przytuła 2014a].

While analysing the migration tendencies, S. Castels and M. Miller [2011, p. 283] arrived at the conclusion that the phenomenon of migration in the years to

${ }^{29}$ The first case of human migration was the expulsion of Adam and Eve from the Garden of Eden. Their migration was a punishment for eating an apple from the tree of knowledge of good and evil. The consequence of such forced migration was the awareness of good and evil, which is one of the reasons for the development of human personality. 
come will gradually intensify, that is it will be larger in terms of number than ever before and will slowly spread throughout the world. It means that many countries will be both the source and the destination of migration. Pursuant to those authors, those migrants will belong to different social and ethnic groups and thus it will be virtually impossible to determine specific waves of migration (e. g. economic, political migration, etc.). Apart from that, the phenomenon of migration feminisation will become more noticeable.

Also M.S. Zięba [2008, p. 24] indicates the complexity and difficulties in the scope of determining the migration phenomena in the future. The number of explicitly defined situations ('an emigrant is someone who has left their country for a long time or permanently') will gradually decrease and we will observe the increased phenomenon of short-term emigration (between a year and 5 years) and the phenomenon of rotational or circular migration (regularly repeated stays lasting less than six months). There will be also an increase in the number of transit countries for other forms of migration (stay for less than a year) - the countries of temporary stay for migrants from which they will emigrate further or return to their home country. The phenomenon of stage migrations (from A to B, and then to $\mathrm{C}$ ) will probably intensify, in particular the return emigrations (from A to $\mathrm{B}$, and then from $\mathrm{B}$ to $\mathrm{A})$. There are many indicators of the growing possibility of occurrence - in the same areas - of the phenomenon of cross migrations (one group emigrates from $\mathrm{A}$ to $\mathrm{B}$ and some other group from $\mathrm{B}$ to $\mathrm{A}$ ).

P. Levitt [1998] developed the term of 'social transfers' (whose idea dates back to the 19-th century 'civilising missions' of Europe in colonies) interpreted as the ideas, models of behaviour, identities and social capital which flow from the communities of host countries to the communities of sending countries. Such influence may be positive and negative. On the one hand, migration means the exchange of ideas) artistic, scientific, political, religious ones), gives the possibility of learning about new visions of the world and opening new horizons, and offers numerous new possibilities of employment. On the other hand, people are afraid of losing their job or decrease in their wages because of the inflow of cheaper workers or the decrease (or increase) in real property prices. Migration is also connected with the growth in organised crime, in particular smuggling and trafficking of human beings, and the increased risk of terrorism, even the increased number of cultural challenges connected with no assimilation - the establishment of new ghettos, riots in the suburbs, threats to the system of values, etc. [Zięba 2008, p. 8]. For there are no guarantees that what migrants learn in their host society will be constructive or influence positively the communities they come from [Castles, Miller 2011, p. 87].

In the literature on the subject, it is hard to find the direct relationship between the migration and expatriation as well as between a migrant and an expatriate. Therefore, it is advisable to make an attempt to locate the phenomenon 
of expatriation against the background of migration processes which have been described in different models and theoretical terms. The key theories of migration include economic theories, historical and structural theories, as well as the theories of migration systems and networks [Castles, Miller 2011, p. 44]. Intensive globalisation processes, technological development as well as increased and diverse mobility go along with the emergence of the need to reconceptualise the notion of 'migration' and other key definitions in migration studies. In response, the researchers started to develop the conception of transnational migration (transmigration) whose aim was to describe the process of creation of spaces across geographic, cultural and political boundaries as a result of social migration in which modern migrants operate. At present, transnationalism becomes a new phenomenon that is different from occupational migration as it leads to the establishment of new social structures in many places around the world such as transnational communities [Beaverstock 2005], and new activities of supra-national character. The emergence of the phenomenon of transnationalism requires the occurrence of three conditions: there is a large number of relationships between human beings across borders which are characterised with fluidity and diversity; transnational activities are characterised with some stability over time; and the content of such activities cannot be captured in the notions and conceptions effective thus far.

The essence of the phenomenon of transnationalism is still human migration but there are also other important criteria such as intensity and 'simultaneity' of participation of people in different social, national, political, etc. spaces [Portes 1999].

The perspective of transmigration started to be used in the analysis of different relationships developed and maintained by migrants (family, economic, social, organisational, religious and political relationships) which cross the borders of nation states [Glick-Schiller et al 1995]. The objective of the research started to concentrate on living spaces and migration projects of transmigrants which cover different geographic areas. The researchers noticed that migrants may build unique bridges between the sending community and the host community and function in the so called 'transnational social spaces' based on interpersonal relationships with the scope covering different countries [Grzymała-Kozłowska 2013]. N. GlickSchiller [1995] defines a transmigrant as a person who - as a consequence of migration - is a member of transnational communities, including also corporations.

It seems that in the group of all other migration theories, the transnational conception covers the issue of expatriation in the widest scope although the term of 'expatriation' does not occur in the publications dealing with transnational theory or transmigration. According to N. Green [2009, p. 307], although expatriation has a long history, this issues have been absent from theoretical and empirical studies of such social subjects as citizenship, migration, emigration. The theoretical discussion 
of expatriation goes on somehow outside problems of migration, emigration, mobility, citizenship, culture, national identity, and sometimes some of these terms are treated as synonyms [ Stownik synonimów; Castle, Miller 2011, p. 339]. Some terms have been adapted from the thematic area of migration for the needs of describing the phenomena in the hosting space in international management. For example, 'circular' or 'temporary' migrations are identical to the phenomenon of rotational, short-term expatriation or cross-border assignments [Castles, Miller 2011, p. 93].

It also happens that some types of expatriation exclude one another or are not found in migration classifications. According to J. Kowaleski [2000, p. 73], in demographic terms, migration does not include the movements arising from tourism, trips for rest, medical treatment, short-term business travels, as well as rotational migration or relocations which involve daily commuting to work between two localities because such relocations do not directly influence the changes in demographic situation either in place of departure or in the place of short term stay. Such definition of migration in demographic terms excludes some forms of expatriation, for example flexpatriate assignments [see: Przytuła 2013] which are short-term (up to 12 months), often also rotational (such as eurocommuting).

Moreover, the theoretical considerations and empirical research concerning expatriation can be found mainly in economic sciences, the discipline of economics, and in management sciences. To be more precise, the issues related to expatriation are included in the following subdisciplines: international management of human resources, international management, international relations, while the issues related to migration are the object of interest of humanities (e.g. sociology, intercultural psychology, political sciences, cultural anthropology).

\section{International employees - the review of definitions}

In 2011 the UN Department of Economic and Social Affairs' Population Division estimates that in 2010 there were 214 million individuals who were undertaking an international mobility. This same report explains that for the period of 2010-2050 the number of individuals moving from developing to more developed countries is expected to be 96 million [for: Al Ariss, Crowley-Henry 2013, p. 79]. No one knows the exact number of international migrants but the data given by the UN and the OECD [for: Castles, Miller 2011, p. 22] states that their number is equal to about $3 \%$ of 6.5 billion people throughout the world.

At present, the occupational and spatial mobility as well as flexibility are key qualifications held by the workers operating in the international environment. Open borders and intensified migration of workers is an element of new reality where an employee has increasingly greater influence on where and how they work and the enterprises expand more and more the scope of searching for candidates also outside the territory of the country where they operate [http://manpower.nf.pl accessed 28. 07. 2015]. 
The worldwide demand for human talents seems limitless with well-educated people transferring between countries and contributing to the world economy [Beaverstock 2005]. As the global landscape is becoming more complex, the range of variations in the categories of globally mobile individuals expands. W dalszej części artykułu zaprezentowane zostaną rodzaje pracowników międzynarodowych, podobieństwa i różnice pomiędzy pojęciami: migrant, assigned expatriate and selfinitiated expatriate.

\section{Migrant}

The United Nations specifies migrant as "any person who changes his or her country of usual residence with the 'country of usual residence' representing the place where the person has the center of his life. Migrant is a person moving from one country in order to settle in another country for a long period of time or permanently [Zikic et al 2010; Cerdin et al 2013]. The Population Organisation at the United Nations defines the permanent place of residence as the stay in one place for at least a year [Kubitsky 2012, p. 9].

The Convention on Migrant Workers (art. 2, \1) [Międzynarodowa Konwencja... 1990] defines the term of 'migrant worker' in the following way: "a person who has been engaged in a remunerated activity in a state of which he or she is not a national". The Convention introduces a new approach in the scope of defining the rights related to some categories of migrant workers and their families, including frontier workers, seasonal workers, seafarers, workers on offshore installations, itinerant workers, project-tied migrant workers, and self-employed workers.

The word 'migrant' denotes both an emigrant and immigrant depending on the direction of their movement. The same person is an emigrant in a country that they leave, and an immigrant in the country they arrive at [Kubitsky 2012, p. 9].

Management studies use the term "migrant" when discussing the work experience of unskilled individuals, having less educated backgrounds and originating from lessdeveloped countries [Al Ariss, Crowley-Henry 2013, p. 82; Castles, Miller 2011, p. 42].

\section{Assigned Expatriate (AE)}

The word 'expatriate' comes from the Latin expatriatus where 'ex' means 'out of' and 'patrià' means 'fatherland'. Thus, the origin of the word 'expatriate (expat)' means a person leaving their fatherland to live outside it [Kopaliński 1994, p. 143].

Traditionally research on international workers has focused on organizational or assigned expatriates (AE) so called because they have been sponsored and assigned by their parent organizations to the foreign location. However the nature and purpose of international assignments are becoming increasingly complex. This has led to a range of new roles and career paths for expatriates [Collings et al 2007]. Some of the emerging populations of expatriates have been termed "interim 
managers" [Feltham, Hughes 1999], "international itinerants” [Banai, Harry 2004], “independent internationally mobile professionals' [McKenna, Richardson 2007], "global nomads" [Matthewman 2011], or "self-initiated expatriates" [Al Ariss 2010]. More recent studies also refer to them as 'migrants" [Al Ariss, Ozbilgin 2010].

Generally, this word 'expatriate' refers to the employees assigned by the international corporations to work abroad to differentiate them from those who are locally employed (and may also be foreigners). However, pursuant to Z. Aycan [2000, p. 192], an expatriate may be an employee of business or government organisation sent to other country than homeland to implement the goals of the organisation. Pursuant to such definition, the politicians (MEPs) may also be defined as expatriates because they sit in the European Parliament as the representatives of their parties. It should be noted that the differentiation found in common usage of the word 'expatriate' usually comes down to socio-economic status of workers as skilled professionals working in another country are described as 'expatriates', whereas a manual labourer who has moved to another country to earn more money might be labelled an 'immigrant' [A1. Ariss, Crowley-Henry 2013]. The use of a given term in relation to a person staying and working abroad is important since it influences pejorative or positive connotation of a given person.

P. Boski [2010, p. 522] refers to the image and perception of migrants in the Polish literature and cinematography through listing the works of such authors as W. Gombrowicz (Transatlantyk - Trans-Atlantic), S. Mrożek (Emigranci - Emigrants), R. Kapuściński (Ten Inny - The Other), E. Redliński (Szczuropolacy - Rat-Poles), or the authors of TV drama series entitled The Londoners - all of them emphasise negative, dysfunctional aspects of emigrants' experience. The people shown in those works are deeply disturbed people who are not adapted to the environment that has become the place of their existence.

In the professional literature of management, the term "expatriate" refers to a specific professional group of employees of international companies. The word usually connotes specialists, engineers, managers (skilled migrants, professionals) sent by their home undertakings (headquarters) to host countries [Bańka 2006, p. 17]. The demographic and professional profile of expatriates proposed by C. Brewster [1991] shows managers, describing their age, sex, background, nationality, objective of expatriation, contract duration. Meanwhile, migration processes involve all groups of moving population of variable age, sex, professional, social and economic structures. Therefore, the material scope of migration is broader than in the case of expatriation.

In view of the aforementioned descriptions of an expatriate, it is possible to formulate the expatriate's definition sensu largo and sensu stricto) [Przytuła 2014a]:

An expatriate sensu largo is:

- a person that has left their homeland; lives and/or works in a country other than their country of origin. 
An expatriate sensu stricto is:

- an employee in an international company, usually a top-ranking specialist or manager who is sent from the corporate headquarters to foreign units (being a subsidiary, branch office, or another legal form of cooperation) pursuant to their voluntary decision. An expatriate may come from the home country of the corporate headquarters or be of different nationality than the home country of the corporation. The length of time of working abroad may be long-, mid-, or short-term, with taking into account different (alternative) forms.

A distinct demarcation between those terms is even harder as these social and cultural phenomena overlap and complement each other. Some authors of literature on humanities apply the terms of 'emigrant' and 'expatriate' interchangeably [Castles, Miller 2011; Giddens 2007, p. 338].

The expatriation may be defined as a specific form of cross-border migration - voluntary, referring to a specified professional group encompassing managers and specialists in international companies, with reasons for it which are rather noneconomic ones (including personal development, motivation to achieve, cognitive curiosity) and are persuasive arguments for going abroad.

The concept of expatriation is tailored rather to the organizational context of crossing borders, whereas the concept of migration is tailored to the general context of crossing geographical borders [Andresen, Bergdolt et al 2013, p. 27].

The dynamics of development of international enterprises and the changes in business environment induce corporations to flexibly adjust to new conditions. Increasingly more often, an assigned expatriate (AE) is replaced by other forms of expatriation encompassing foreign assignments which are shorter, less costly, and more oriented to the completion of a specific project [Beaverstock 2005; see also: flexpatriation in: Przytuła 2013].

\section{Self-initiated expatriate (SIE)}

New trends in international assignments are characterized by individuals who personally take responsibility of their careers without the direct support of an organization [Carr, Inkson, Thorn 2005]. Such individuals who themselves make the decision to live and work abroad have been called self-initiated expatriates. K. Inkson et al [1997] introduced category of "self-initiated foreign work experienceSFE" which was developed by Suutari and Brewster [2000], also "self-selecting expatriates" [Richardson, McKenna 2003], "self-initiated movers" [Thorn 2009], "self-designed apprenticeship" [Arthur et al 1999], "free travelers" [Myers, Pringle 2005] but the nomenclature SFE has converged to the widely accepted "SIE" category of international assignee [Al Ariss, Crowley-Henry 2013] $]^{30}$. The key distinction between SIEs and AEs is the initiative for the move [Cerdin, Selmer 2014, p. 1282].

${ }^{30}$ More detailed review of SIEs' definitions in: Cerdin, Selmer 2014. 
SIE are professionals who choose to expatriate and who are not transferred by their employer [Harrison et al 2004], they relocate to a country of their choice to seek a job or to try an entrepreneurial venture [Jokinen et al 2008; Saxenian 2005]. So SIEs initiate their own expatriation than are assigned by their company, as shown from professionals from Western countries (65\% self-initiated expatriates vs. 35\% assigned expatriates) [Doherty et al 2008].

It is possible to specify the following subgroups within such population [Suutari, Brewster 2000]:

- young opportunists being young people (aged up to 30) who stay abroad with the prolonged stay within travelling and tourism and work. Pursuant to the research carried out in 2000, this type of SIEs constituted $15 \%$;

- job seekers do not have any work or are not satisfied with their present job and the possibilities of professional development (there were about $25 \%$ of them);

- officials are the employees taken on by such international organisation as e. $g$. the United Nations or the European Union (about 12\% of respondents);

- localized professionals who went to foreign assignments as AEs but decided to rather stay in the host country than to come back to the home country after the completion of their assignments (about $7 \%$ of the sample);

- international professionals being global careerists, hires, international itinerants) [Banai, Harry 2004; Jokinen et al 2010; Makela, Suutari 2009] are people with considerable experience in working for international entities, often for many different corporations, and belonging to the group of those who earn the most (about 25\%);

- dual career couples mean that an expatriate's partner or spouse find employment for themselves in the host country (there were about $38 \%$ of them).

Cerdin and Selmer [2013, p. 1289] define 4 conditions which must all be fulfilled at the same time in order to define a person as an SIE:

- self-initiated international relocation takes into account both the beginning of a foreign assignment and its end, that is the return to the home country, without the financial and organisational assistance from the corporation for which an SIE works. This criterion definitely makes a difference between SIEs and assigned expatriates (AEs) who may also initiate their foreign assignments, yet they are supported by their organisation in the scope of moving abroad and return from there.

- regular employment intentions - SIEs are not immigrants or short-term travellers sojourners) [Richardson, Zikic 2007]. They are foreign employees who temporarily stay outside the country of their origin. The criterion distinguishing SIEs from sojourners (who may be foreigners visiting another country for a short period of time) is the requirement of regular employment. It often happens that a person considers a foreign assignment as too difficult and complex in terms of organisational, administrative and financial issues, and therefore they go abroad 
supported by a corporation as an $\mathrm{AE}$ and take advantage of the assistance given by the sending entity. However, during their stay in a host country, they may become SIEs when they resign from work for their home undertaking and find the work in another local company on their own. Thus, the criterion of regular work is a criterion used to classify a given person as an SIE [Cerdin, Selmer 2013, p. 1292].

- intentions of a temporary stay in the host country constitute a criterion that distinguishes SIEs from immigrants who relocated abroad with the intention of staying abroad for a long period of time or permanently [Cerdin, Selmer 2013, p. 1289]. A. Haslberger and V. Vaiman [2009] note the temporary nature intended even if open ended' of self-initiated expatriation. It is a very subjective criterion and the problem with its fulfilment refers to time because at the moment of departure to a host country, an SIE may not have clearly specified period of stay, it is an open contract for them. It often happens that a person going abroad for a period of time determined in advance changes their plans for life and stays in the host country permanently. In such a case, such a person may be classified as an SIE.

- professional qualification - SIEs are highly qualified specialists who can find employment for themselves in a foreign labour market [Haleberger, Vaiman 2009]. Thus, self-initiated expatriation is considered as the experience supporting the international professional career [Al Ariss, Ozbilgin 2010]. The researchers emphasise that international corporations make use of SIEs and treat them as an antidote to shortage of qualified managerial staff in host markets [Banai, Harry 2004; Suutari, Brewster 2000]. Furthermore, SIEs are strategically valuable human resources for multinational corporations [Howe-Walsch, Sschyns 2010] and growing numbers of them are employed by organizations [Jokinen et al 2008]. It should be emphasized that it is possible to distinguish the representatives of the SIEs only if they fulfil all criteria at the same time. For there are many examples of international employees who fulfil only 3 criteria at a given time and they cannot be granted the status of an SIE. For example, the partners or spouses accompanying the expats may meet the criteria $b, c, d$, yet the criterion $a$ is not applicable to them. Immigrants fulfil the criteria $a, b, d$ but not $c$. Also foreign students fulfil the criteria $a, c, d$ but do not meet the criterion $b$.

\section{The criteria for differentiating terms of migrant, assigned expatriate and self-initiated expatriate}

The objective of this article was to specify the demarcation criteria for such terms as migrant, AE and SIE. Pursuant to Andres, in spite of the fact that SIEs belong to the group of AEs (they originated from them), the research conceptions and studies devoted to this group of international employees should constitute 
a separate discipline. The noticeable development of the thematic area of migration and expatriation, which is demonstrated by the developed differences and similarities between those three groups of international employees, should result in the separation of those constructs, conceptions and models. Because migrants, AE, and SIE represent different types of internationally mobile employees, research results cannot be transferred between these distinct groups [Andresen, Al Ariss, Walther 2013, p. 3].

The proposal by M. Andresa et al. [2013, p. 30] is presented below and it is based on the analysis of 244 definitions of the aforementioned terms shown from different perspectives (sociological, psychological and economic) in the articles and research studies published thus far. The authors described the decision algorithm which is used to differentiate between a migrant, assigned expatriate and SIE.

Figure 1. Decision tree

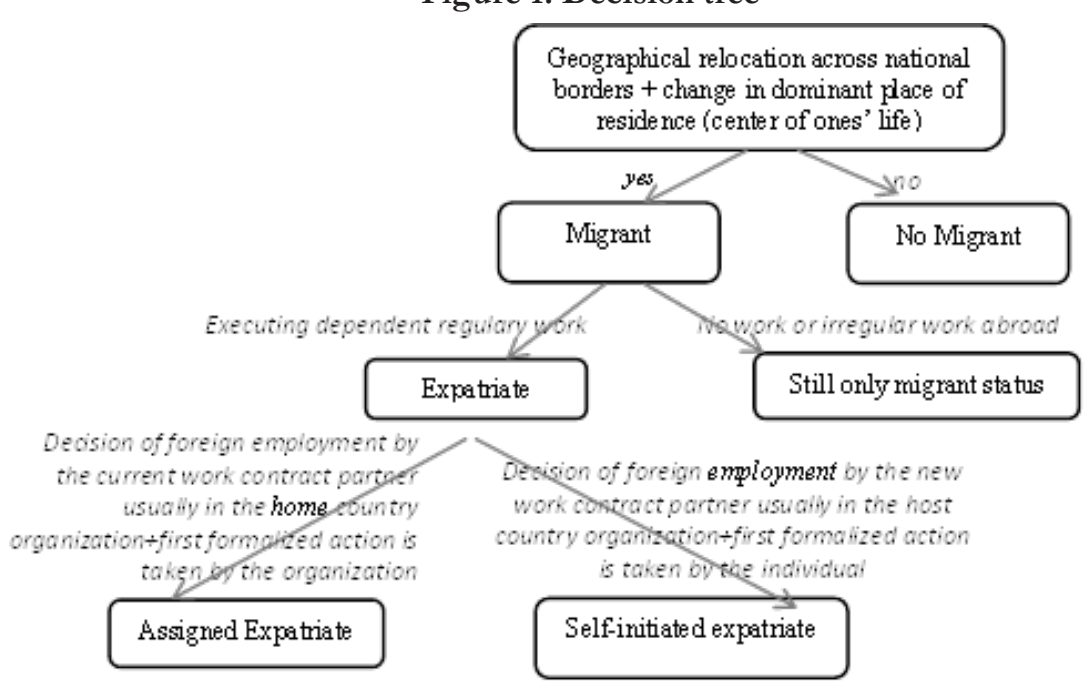

Source: adapted from: Andresen, Bergdolt, Margenfeld 2013, p. 30.

The decision tree concerning the employment abroad shows the following steps. A migrant is a person that relocates from one geographical point to another and at the same time changes their place of residence (the place of their stay thus far) which constituted the centre of their personal life. While an expatriate is a person that relocates from one geographical point to another and at the same time changes their place of residence (the place of their stay thus far) which constituted the centre of their personal life and does professional work in another country. If a person does not fulfil the last criterion (that is does not do permanent or even irregular work abroad), then such a person still holds the status of a migrant. 
If the initiative and formalized activities concerning a foreign assignment are undertaken by a company/organisation which has been employing a given person in a home country of this organisation thus far, then such a person belongs to the category of an assigned expatriate (AE). SIEs are different from them as they demonstrate an individual initiative in the scope of taking up work abroad. Formalized activities concerning the employment and legal stay abroad are carried out by the expats themselves and possibly by a new employer in a host country.

Then a self-initiated expatriates move across different organizations, and traditional expats move within the boundaries of one organization [Andresen, Bergdolt, Margenfeld 2013].

Bearing in mind that the demarcation lines between a migrant, AE and SIE are not always so explicit in reality as it is presented in theoretical models, it is advisable to define additional and more detailed criteria to differentiate those three terms.

Table 1. Differences between migrant, assigned expatriate and self-initiated expatriate

\begin{tabular}{|c|c|c|c|c|}
\hline & $\begin{array}{l}\text { Differentiating } \\
\text { criteria }\end{array}$ & Migrant & Assigned expatriate & Self-initiated expatriate \\
\hline 1 & $\begin{array}{l}\text { organizational } \\
\text { affiliation }\end{array}$ & $\begin{array}{l}\text {-employment is not } \\
\text { compulsory and } \\
\text { necessary; often } \\
\text { doesn't occur }\end{array}$ & $\begin{array}{l}\text {-employed by one } \\
\text { corporation; } \\
\text {-is obliged to take } \\
\text { assignment suggested by } \\
\text { the corporation; } \\
\end{array}$ & $\begin{array}{l}\text {-is not permanently } \\
\text { associated with any } \\
\text { organization; } \\
\text {-can also work with several } \\
\text { organizations; }\end{array}$ \\
\hline 2 & $\begin{array}{l}\text { organization of } \\
\text { foreign mission } \\
\text { and financial } \\
\text { support }\end{array}$ & $\begin{array}{l}\text { - many scenarios } \\
\text { are possible- self- } \\
\text { organization or } \\
\text { with the support } \\
\text { of family; or with } \\
\text { government/ } \\
\text { non-governmental } \\
\text { institutions, } \\
\text {-costs of relocation } \\
\text { are paid from } \\
\text { private funds, the } \\
\text { possible financial } \\
\text { support of various } \\
\text { organizations, f.ex. } \\
\text { Red Cross, UN }\end{array}$ & $\begin{array}{l}\text { - a high level of support } \\
\text { from the sending and } \\
\text { the receiving unit } \\
\text { (preparation, staying } \\
\text { for expat and his family, } \\
\text { return and support } \\
\text { on matters not related } \\
\text { to their professional } \\
\text { work is ensured by } \\
\text { the corporation and } \\
\text { a subsidiary) } \\
\text {-costs related to } \\
\text { relocation covers the } \\
\text { sending and/or receiving } \\
\text { organization }\end{array}$ & $\begin{array}{l}\text {-independently organizing } \\
\text { the trip (usually without } \\
\text { the involvement of family } \\
\text { members); } \\
\text {-no support from the host } \\
\text { organization on matters } \\
\text { unrelated to work; } \\
\text { - private funds for } \\
\text { relocation }\end{array}$ \\
\hline 3 & $\begin{array}{l}\text { intended } \\
\text { period of } \\
\text { staying abroad }\end{array}$ & $\begin{array}{l}\text { - unlimited, long- } \\
\text { term with the } \\
\text { intent to remain } \\
\text { permanently in the } \\
\text { host country }\end{array}$ & $\begin{array}{l}\text {-limited-working for } \\
\text { a subsidiary corporation } \\
\text { for the time specified in } \\
\text { the contract, } \\
\text {-usually they are, once or } \\
\text { repeatedly trips lasting } \\
\text { from } 1-5 \text { years; }\end{array}$ & $\begin{array}{l}\text {-unlimited- length of stay } \\
\text { abroad depends on the } \\
\text { duration of the project or } \\
\text { task, but also on individual } \\
\text { plans and decisions of SIE; } \\
\text {-missions are frequent, but } \\
\text { brief; }\end{array}$ \\
\hline
\end{tabular}




\begin{tabular}{|c|c|c|c|c|}
\hline 4 & $\begin{array}{l}\text { motives of } \\
\text { going abroad }\end{array}$ & $\begin{array}{l}\text { - mainly economic } \\
\text { and non- } \\
\text { economic (external } \\
\text { compulsion) } \\
\text { - economic (labour) } \\
\text { - physical work } \\
\text { prevails, the income } \\
\text { there from is for } \\
\text { distant goals and it } \\
\text { requires sacrifice of } \\
\text { other spheres of life } \\
\text { - non-economic } \\
\text { (eg. unstable } \\
\text { political situation } \\
\text { of the country, war, } \\
\text { unemployment, } \\
\text { natural disasters, } \\
\text { persecution, etc.) }\end{array}$ & $\begin{array}{l}\text {-organizational motives } \\
\text { are predominant (filling } \\
\text { in the staffing gaps in } \\
\text { the local market; control } \\
\text { and coordination of the } \\
\text { activities of subsidiaries } \\
\text { abroad) } \\
\text {-economic (improvement } \\
\text { of living standard, } \\
\text { financial situation); } \\
\text { in comparison with } \\
\text { migrants, expatriates do } \\
\text { not perceive their job in } \\
\text { categories of "sacrifice" } \\
\text { and "earning their living" } \\
\text { as much as migrants, } \\
\text { - non-economic (related } \\
\text { to internal development) } \\
\text { - the expats derive } \\
\text { satisfaction from } \\
\text { their work abroad and } \\
\text { consider it an important } \\
\text { stage in their personal } \\
\text { development } \\
\text {-family issues }\end{array}$ & $\begin{array}{l}\text {-individual and personal } \\
\text { motives are predominant } \\
\text { (travel, adventure, lifestyle } \\
\text { change, escape from the } \\
\text { problems) } \\
\text { - work abroad is a voluntary } \\
\text { choice of the so-called } \\
\text { "voluntary displacement" } \\
\text { [Furnham 2010, p.29], } \\
\text { - building own career paths } \\
\text { (boundaryless career) } \\
\text { - increasing his/ } \\
\text { her market value and } \\
\text { employability as a result } \\
\text { of the acquired unique } \\
\text { knowledge, experience, } \\
\text { and interpersonal relations } \\
\text { (networking) }\end{array}$ \\
\hline 5 & $\begin{array}{l}\text { socio-cultural } \\
\text { adaptation and } \\
\text { perception in } \\
\text { host countries }\end{array}$ & $\begin{array}{l}\text { - preparation } \\
\text { for working and } \\
\text { living in a foreign } \\
\text { country is on the } \\
\text { side of the migrant, } \\
\text { sometimes even } \\
\text { with the support of } \\
\text { institutions } \\
\text {-ability to adapt } \\
\text { and integrate in the } \\
\text { host country greater } \\
\text { than in case of } \\
\text { AEs, because of the } \\
\text { intention of long- } \\
\text { term or permanent } \\
\text { stay } \\
\text { - rather negative } \\
\text { connotation in } \\
\text { the host country } \\
\text { (immigrants, } \\
\text { "outsiders", } \\
\text { "foreigners") }\end{array}$ & $\begin{array}{l}\text { - adaptation program } \\
\text { (intercultural training, } \\
\text { language courses } \\
\text { for expat and family } \\
\text { members) is organized by } \\
\text { sending and continued by } \\
\text { receiving unit; } \\
\text {-life in expats' enclaves, } \\
\text { poor integration with the } \\
\text { local staff and inhabitants } \\
\text { due to the feeling of } \\
\text { "temporariness" } \\
\text { - rather positive } \\
\text { perception }\end{array}$ & $\begin{array}{l}\text { - greater than in AEs case } \\
\text { the ability to integrate with } \\
\text { the local community, } \\
\text {-better understanding of } \\
\text { local culture and easier } \\
\text { adaptation } \\
\text {-preparation to live and } \\
\text { work in a foreign country } \\
\text { and culture on his/her own } \\
\text { - rather positive perception }\end{array}$ \\
\hline
\end{tabular}




\begin{tabular}{|c|c|c|c|c|}
\hline 6 & $\begin{array}{l}\text { Direction of } \\
\text { transfer }\end{array}$ & $\begin{array}{l}\text {-crossing national } \\
\text { boundaries } \\
\text { - from developing } \\
\text { countries to } \\
\text { developed countries }\end{array}$ & $\begin{array}{l}\text {-crossing national but not } \\
\text { organizational boundaries } \\
\text { - from developing } \\
\text { countries to developed } \\
\text { countries; however, the } \\
\text { prevailing direction is } \\
\text { from developed countries } \\
\text { (where headquarters } \\
\text { are usually located) } \\
\text { to emerging markets } \\
\text { (prospective, yet } \\
\text { problematic destinations) }\end{array}$ & $\begin{array}{l}\text {-crossing national and } \\
\text { organizational boundaries } \\
\text {-SIEs display higher than } \\
\text { expatriates organizational } \\
\text { mobility and intention to } \\
\text { change organization }\end{array}$ \\
\hline 7 & $\begin{array}{l}\text { citizenship/ } \\
\text { national } \\
\text { identity }\end{array}$ & $\begin{array}{l}\text {-the immigrants } \\
\text { who decide to stay } \\
\text { permanently change } \\
\text { their citizenship } \\
\text { and participate in } \\
\text { stay legalisation } \\
\text { programmes }\end{array}$ & $\begin{array}{l}\text { - expatriates have } \\
\text { the citizenship of the } \\
\text { country of their origin } \\
\text { (often identical with } \\
\text { the HQ country of } \\
\text { origin),although they } \\
\text { work and live abroad } \\
\text { - the country of origin } \\
\text { and its political life are } \\
\text { major object of interest. }\end{array}$ & $\begin{array}{l}\text {-SIEs change countries and } \\
\text { the organizations in which } \\
\text { they work, but they remain } \\
\text { citizens of their own } \\
\text { country of origin }\end{array}$ \\
\hline 8 & \begin{tabular}{|l} 
Level of \\
assurance, \\
safety and job \\
satisfaction
\end{tabular} & \begin{tabular}{|l}
-significant \\
uncertainty \\
connected with the \\
initial period of \\
searching for job, \\
worrying about the \\
maintenance of one's \\
family
\end{tabular} & $\begin{array}{l}\text { - job security during the } \\
\text { term of the contract, } \\
\text {-no organizational } \\
\text { solutions for repatriates } \\
\text { in terms of jobs and place } \\
\text { in the corporate structure } \\
\text { makes them leave the } \\
\text { organization } \\
\text { - wide range of financial } \\
\text { incentives, various forms } \\
\text { of economic support for } \\
\text { families, high level of } \\
\text { satisfaction from work }\end{array}$ & $\begin{array}{l}\text {-reliability and job safety } \\
\text { depend on the SIE-alone } \\
\text { decides about having a job } \\
\text { or finished contract } \\
\text {-job satisfaction very high }\end{array}$ \\
\hline
\end{tabular}

Source: Doherty, Dickmann, Mills 2011, p. 605; Selmer, Lauring 2010, p. 170; Sargent 2002, p. 3071; Biemann, Andresen 2010; Al Ariss 2010; Castles, Miller 2011, p. 339; Purgał-Popiela 2011, p. 95.

One of the differences that determine the types of international employees is the level of autonomy and dependence towards an organisation. In the case of a migrant, the affiliation to an organisation is not required and it often does not exist. One of the differences between these types of international workers is the level of autonomy and dependence to the organization. In the case of migrant, organizational affiliation is not required and often does not occur. Whenever the discussion uses the term "migrant", the emphasis is on work/employment (rather 
than careers) that often occur under hursh conditions of under-employment and even unemployment [Al Ariss, Crowley-Henry 2013, p. 82]. An expatriate is 'a man of the organisation' and they usually come from the country where the headquarters are located - the country of destination and the duration of assignment are usually determined by a corporation. Pursuant to the research by Brookfield Global Relocation Services [2015, p. 36], 57\% of assigned expatriates are the employees of corporate headquarters. In the case of SIEs, the foreign assignment, its duration and place of destination are selected by themselves. Self-initiated expatriation is connected more closely with the pursued profession than with the affiliation to an organisation.

Another distinguishing criterion is the organisation of foreign assignment and financial support. In the case of migrants, there are many possible scenarios. Migrants organize their journey and stay in the country of destination on their own or with the support of government and non-government institutions. The costs of relocation are covered from private means. The financial support of different organisations, e. g. humanitarian ones, is also possible. Expatriates may rely on the support from their sending and host entities (preparations, stay for an expat and their family and return, as well as the on-going assistance in issues which are not related to professional job are provided by a corporation or its subsidiary). The costs connected with relocation are covered by the sending and/or host organisations. Furthermore, the research by Brookfield Global Relocation Services [2015] shows that majority of companies applies total reimbursement of relocation costs.

Figure 2. Reimbursement of costs and expenses related to relocation of assigned expatriate (data in \%)

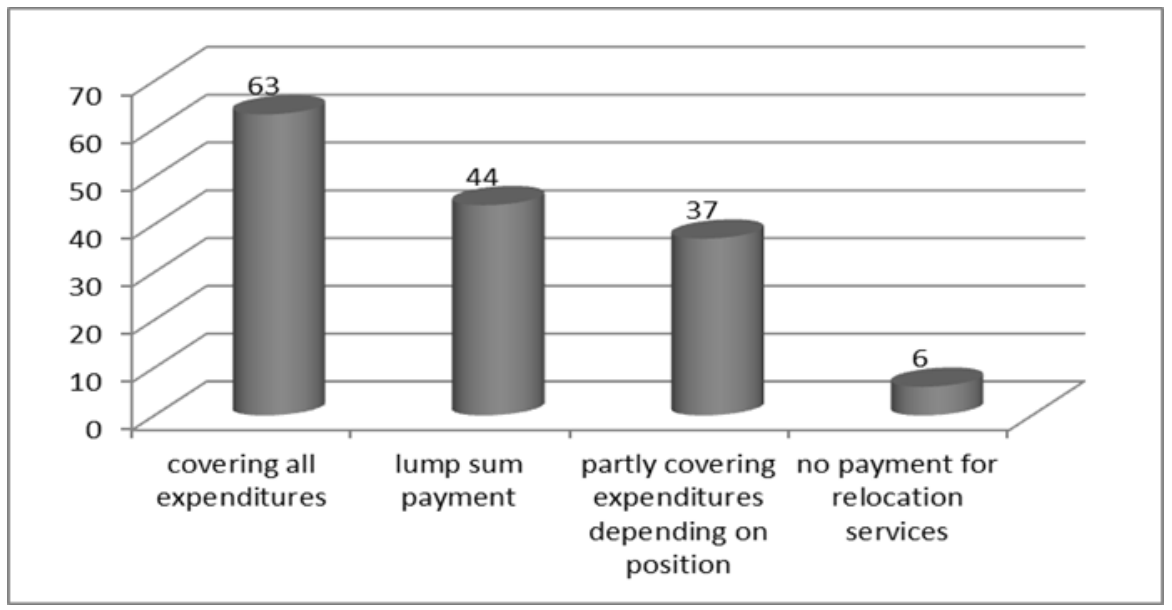

Source: Brookfield Global Relocation Services 2015 
SIEs organize their journey on their own (usually without the participation of their family members) and use private financial means for relocation.

Given the intention of stay abroad, the migrants' stay in a host country may be unlimited, long-term with the intention to stay permanently. Expatriates' stay is limited - they work in a subsidiary of their corporation for a term determined in the assignment and there may be one or several stays abroad lasting from 1 year to 5 years. For SIEs, the length of their stay abroad is unlimited - it depends on the duration of a project or task but also on the expatriate's individual plans and decisions. They go abroad frequently but for a short time.

One of the significant criteria that define whether a person is a migrant, $\mathrm{OE}$ or SIE is the motive for working abroad. For migrants, the necessity or the need to relocate to another country is a result of an individual decision or it is a 'compulsion' arising from economic, political, religious circumstances prevailing in the country of their origin, e.g. unstable political situation, war, unemployment, natural disasters, persecution, etc.

In the case of expatriates, the prevailing motives are the organisational ones (to fill in the vacancies in the local market; to control and coordinate the business activities of a foreign subsidiary), and also the motives related to self-development - expats derive satisfaction from working abroad and consider it as an important stage in their own development, the possibility of gaining intercultural experience, and greater chances of promotion in corporate structure. They are also driven by economic motives although in comparison with migrants, assigned expatriates perceive their job in categories of 'sacrifice' and 'earning their living' to a lesser degree. At this point, it would be advisable to indicate two groups of motives for making decisions about foreign assignments by assigned expatriates in the literature on the subject:

Table 2. Motives of expatriation-organizational and individual perspective

\begin{tabular}{|l|l|}
\hline Organizational perspective & Individual perspective \\
\hline $\begin{array}{l}\text { Managerial development } \\
\text { (building a team of international managers, } \\
\text { network's ties and interpersonal relationships, } \\
\text { broaden intercultural experience in corporation) }\end{array}$ & $\begin{array}{l}\text { Development of professional skills and } \\
\text { managerial experience }\end{array}$ \\
\hline $\begin{array}{l}\text { Control and coordination of local business } \\
\text { (control costs and achieve business goals, solving, } \\
\text { operational and technical problems, ,putting out } \\
\text { fires”) }\end{array}$ & $\begin{array}{l}\text { Cognitive curiosity } \\
\text { (willingness to explore new countries and } \\
\text { cultures, learning a foreign language, the } \\
\text { desire to gain the experience of work and life } \\
\text { in the country) }\end{array}$ \\
\hline $\begin{array}{l}\text { Lack of qualified locals } \\
\text { (lack of local resources of knowledge, filling the } \\
\text { gaps in the field of knowledge, managerial skills } \\
\text { and technical in the host country) }\end{array}$ & $\begin{array}{l}\text { Personal motives } \\
\text { (family and social links with the host country, } \\
\text { the desire to escape from personal problems) }\end{array}$ \\
\hline
\end{tabular}




\begin{tabular}{|l|l|}
\hline $\begin{array}{l}\text { Transfer of knowledge, culture, technology } \\
\text { (endeavour new solutions) }\end{array}$ & $\begin{array}{l}\text { Economic motives } \\
\text { (improving financial conditions) }\end{array}$ \\
\cline { 2 - 2 } & $\begin{array}{l}\text { Career support } \\
\text { (creating better perspectives for career) }\end{array}$ \\
\hline
\end{tabular}

Source: Przytuła 2014 a.

In relation to SIEs, the research findings of Doherty N. and Dickmann M., [2013, p.131] proved that the motivational drivers reported as having a considerable influence on the decision to take up SIE careers were topped by the: desire for adventure, the individual's perceived confidence in their ability to work/live abroad and the desire to see the world. SIE are influenced by factors which are often outside the gift of institutional or organizational influence. This practice has been also confirmed in other studies:

- SIE are driven by subjective inner sense of adventure, a desire to travel and to see the world, to meet career goals escape from current circumstances [Doherty et al 2011; Carr, Inkson Thorn 2005],

- SIE wants to improve his/her lifestyle and quality of living rather than move for economic reasons [Richardson, McKenna 2003],

- SIEs want to learn about different cultural settings and establishing new international contacts [Myers, Pringle 2005],

- for SIEs foreign missions mean growth of cross-cultural experience, career prospects, excitement, meeting new and different people [Tharenou 2003].

Opportunities to SI expatriate arose by chance rather than as a result of specific plan and when considering the option to move, desire for adventure, life change and benefit to the family were primary incentives to work abroad [Doherty, Dickmann 2013, p. 450].

Another important criterion is social and economic adaptation in a host country. The preparations for work and life in a foreign country are the migrants' responsibility and it also happens that they are supported by institutions. Adaptation and integration in the host country is bigger for migrants that for AEs because of the intention to stay for a long time or permanently. Immigrants perceive their host country as their new home and therefore they are more inclined to assimilate and integrate and they try to adapt to new values and cultural standards in the country with which they associate their future. However, migrants are perceived in the host country rather negatively - they are called 'intruders', 'outsiders', 'the others').

Preparations for adaptation (intercultural trainings, language courses for expats and their family members) are provided by sending and host organisations (56\% of companies offers such preparations to the expat's whole family, and $35 \%$ for an expat and their spouse/partner) [Brookfield... 2015, 81]. Nevertheless, expatriates' integration with local staff and population is small and they rather live in expatriates' enclaves. The feeling of 'temporariness' of their stay causes that they do not want 
to get emotionally involved in interpersonal relations. Their perception in the host country is rather positive [Przytuła et al 2014b, p. 20; Przytuła 2014c, pp. 14-15].

Self-initiated expatriates report greater cultural adjustment, ability to adapt to the host country and confidence in their capacity to live and work abroad than company expatriates [Doherty, Dickmann 2008; Peltokorpi, Froese 2009]. Their understanding of the local culture is better and thus their adaptation is easier [Sargent 2002]. SIEs highly appreciate interpersonal relations [Bozionelos 2009] which are more important for them than culture-related preparations of formal nature (e.g. participation in intercultural trainings). As the decision about the country of relocation is based on their own initiative, they are driven by e. g. the knowledge of its culture, they know the local language, which significantly facilitates their adaptation and speeds up cultural immersion. Some studies also demonstrate the differences in the level of emotional adaptation which are noticeable in people leaving the country of their origin (see: Krzyżowski 2010, pp. 172-185]. SIEs are perceived positively in the host country.

Direction of relocation for migrants is from developing countries to developed countries. Migrants cross national boundaries while OEs cross national but not organizational boundaries. The prevailing direction for them is from the developing countries (where the headquarters are usually located) to emerging and developing markets.

SIEs cross national and organizational boundaries, moreover they display higher than expatriates organizational mobility and intention to change organization [Biemann, Andresen 2010].

In the scope of issues related to citizenship and national identity, immigrants who decide to stay permanently in the host country change their citizenship and participate in the schemes of legalisation of their stay. Expatriates are still the nationals of the country of their origin (which is also the country where the headquarters are located) although they work and live abroad for a long time, that is up to 5 years. SIEs often change countries and organisations they work for but they remain the nationals of their country of origin.

Given the level of certainty, guarantee and satisfaction from work, considerable uncertainty accompanies the migrants in the initial period of searching for work, there are financial problems as well as issues connected with language and social adaptation. Expatriates have the guarantee of employment, advantageous financial conditions during their assignment and after its completion. Yet, the lack of satisfactory organisational solutions for repatriates in the scope of positions in the corporate structure causes that $26 \%$ of them decide to leave the corporation within 2 years of their return from assignment [Brookfield... 2015, p. 81], and $86 \%$ of the researched companies have no formal repatriation strategy linked to career management and retention [Brookfield.... 2015, p. 53]. During the term of 
the assignment, AEs are offered a wide array of financial incentives also for their families. It results in high level of general satisfaction and satisfaction from work. In the case of SIEs, the certainty and guarantee of work depend on themselves. SIEs are the ones who decide if they work or terminate their employment.

\section{Conclusion}

The phenomenon of migration, in particular of transnational migration, will intensify in the years to come. Political, economic, social, religious, etc. factors determine the diversity of foreign relocations and types of international employees. The goal of this article has been to define the demarcation lines for such terms as migrant, AE and SIE, as well as to make an attempt to place the issue of expatriation against the background of migration considerations.

The proposal of numerous criteria distinguishing those terms constitutes not only the epistemological contribution but may be also helpful in empirical studies, the selection of respondents to studies on migration or expatriation. It is also advisable to appeal to the researches dealing with the issue of international mobility for interdisciplinary cooperation (from such areas as regional policy, social policy and demography, ethnology, sociology and political sciences, management sciences) within the area of the humanities and social sciences, which would enrich the scientific and research output in the scope of migration and expatriation with new solutions, conceptions and models.

The review of the literature on the subject and the existing research studies is the basis for asking the questions about further directions of research in the discussed subject, e.g.:

- What are the tendencies in the scope of employment of expatriates and SIEs in global companies?

- What is the course of the SIEs' foreign assignment - from planning to their return?

- What are the advantages and problems of self-initiated expatriation for an organisation and an expatriate?

- What is the form of knowledge transfer in the case of self-initiated expatriation?

\section{Bibliography}

Agozino B. (2000), Theoretical and methodological issues inmigration reserach: interdysciplinary, intergenerational and international pespectives, Aldershot Hants: Ashgate.

Al Ariss A. (2010), Modes of engagement: migration, self-initiated expatriation, and career development, "Career Development International”, Vol.15, No. 4.

Al Ariss A., Crowley-Henry M. (2013), Self-initiated expatriation and migration in the management literature. Present theorizations and future research directions, "Career Development International", Vol.18, no 1. 
Al Ariss A., Ozbilgin M. (2010), Understanding Self-Initiated Expatriates: career experiences of Lebanese self-initiated expatriates, "Thunderbird International Business Review”, 52, 4.

Andresen M., Al Ariss A., Walther M. (2013), Introduction [in:] Andresen M., Al Ariss A., Walther (eds.) Self-Initiated Expatriation. Individual, Organizational and National Perspectives, Routledge, New York-London.

Andresen M., Bergdolt F., Mergenfeld, J. (2013), What distinguishes self-initiated expatriates from assigned expatriates and migrants? [in:] Andresen M., Al Ariss A., Walther M. (eds.) Self-Initiated Expatriation. Individual, Organizational and National Perspectives, Routledge, New York-London.

Arthur M.B., Inkson K., Pringle J.K (1999), The New Careers: individual action and economic change, London: Sage.

Aycan Z, Kanungo R., Mendonca M., Yu C., Deller J., Stahl G., Kurshid A. (2000), Impact of culture on buman resources management practices: 10-country comparison, "Applied Psychology: an International Review", no 59(1).

Banai M., Harry W. (2004), Boundaryless global careers, "International Studies of Management and Organization", 34(3).

Bańka A. (2006), Poradnictwo transnacjonalne, Ministerstwo Pracy i Polityki Społecznej, Departament Rynku Pracy, Warszawa.

Bevarstock J.V. (2005), Transnational elites in the city: British highly-skilled inter-company transferees in New York City's financial district, "Journal of Ethnic and Migration Studies", 31, 2.

Biemann T., Andresen M. (2010), Self-initiated foreign expatriates versus assigned expatriates, “Journal of Managerial Psychology', 25.

Boski P. (2010), Kulturowe ramy zachowań społecznych, PWN, Warszawa.

Boyle P., Halfacree K., Robinson V. (1998), Exploring contemporary migration, Harlow: Addison Wesley Longman.

Bozionelos N. (2009), Expatriation outside the boundaries of the multinational corporation: a study with expatriate nurses in Saudi Arabia, "Human Resource Management", vol. 48, no 1.

Brewster C. (1991), The management of expatriates, London, Kogan-Page.

Brookfield Global Relocation Services, 2015, http://www.globalrelocationtrends.com

Cappellen T., Janssens M. (2010), Characteristics of international work: narratives of global manager, “Thunderbird International Buisness Review", vol. 34, no 3.

Carr S., Inkson K., Thorn K. (2005), From global careers to talent flow: reinterpreting "brain drain", "Journal of World Business", 40(4).

Castles S., Miller M. (2011), Migracje we wspótczesnym świecie, PWN, Warszawa.

Cerdin J., Adbeljalil D., Brewster C. (2013), Qualified Immigrants' Success: Exploring the motivation to migrate and to integrate, "Journal of International Business Studies", doi:10.1057/ jibs.2013.45.

Cerdin J., Selmer J. (2014), Who is a self-initiated expatriate? Towards conceptual clarity of a common notion, "The International Journal of Human Resource Management", Vol. 25, no 9. 
Collings D., Scullion H., Morley M. (2007), Changing patterns of global staffing in the multinational enterprise: challenges to the conventional expatriate assignment and emerging alternatives, "Journal of World Business", 42(2).

Dickman M., Doherty N. (2010), Exploring organizational and individual career goals, interactions and outcomes of developmental international assignments, "Thunderbird International Business Review", vol. 52, no 4.

Doherty N., Dickmann M. (2013), Self-initiated expatriation. Drivers, employument experience and career outcomes [in:] Andresen M., Al Ariss A., Walther M. (eds.), Self-Initiated Expatriation. Individual, Organizational and National Perspectives, Routledge, New York-London.

Doherty N., Dickmann M., Mills T. (2011), Exploring the motives of company-backed and selfinitiated expatriates, "International Journal of Human Resource Management”, 22.

Doherty N., Dickmann M., Mills T. (2008), Career activities or active careerists?, Paper presented at the $24^{\text {th }}$ EGOS Colloqium, Amsterdam, July 10-12.

Doherty N., Richardson J., Thorn K. (2013), Self-initiated expatriation. Career experiences, processes and outcomes, "Career Development International", Vol.18, no 1.

Feltham R., Hughes D. (1999), Interim managers: distinguishing personality characteristics of managers on short-term contracts, "International Journal of Selection and Assessment", vol.7, no 4.

Furnham A. (2010), Human mobility in global era [in:] S.C. Carr (ed.), The Psychology of Global Mobility, Springer Science and Business Media.

Giddens A. (2007), Socjologia, Warszawa.

Glick-Schiller N., Basch L., Szanton-Blanc C. (1995), From Immigrant to Transmigrant: Theorizing Transnational Migration, "Anthropological Quarterly", 68(1).

Green N. (2009), Expatriation, expatriates and expats. The American transformation of a concept, "American Historican Review", April.

Grzymała-Kozłowska A. (2013), Ku socjologii mobilnego społeczeństwa?, „Studia Socjologiczne”, 3 (210).

Harrison D.A., Shaffer M.A., Bhaskar-Shrinivas P. (2004), Going places: Roads more or less traveled in research on expatriate experiences [in:] J.J. Martochio (ed), Research in personnel and human resources management, vol.23.

Haslberger A., Vaiman V. (2009), Self-initiated expatriates: a neglected source of the global talent flow [in:] V. Vaiman, A. Haslberger (eds.), Talent Management of Self-Initiated expatriates: a neglected source of global talent, Hamshire: Palgrave Macmillan.

Howe-Walsh L., Schyns B. (2010), Self-initiated expatriation: implication for HRM, "The International Journal of Human Resource Management", 21,2.

http://manpower.nf.pl accessed 28.07.2015.

Inkson K., Arthur M.B., Pringle J., Barry S. (1997), Expatriate Assignment versus overseas experience: International Human Resource Development, "Journal of World Business", 2.

Jokinen T., Brewster C., Suutari V. (2008), Career Capital During International Work Experiences: contrasting self-initiated expatriate experiences and assigned expatriation, "The International Journal of Human Resource Management", 19,6. 
Kawczyńska-Butrym Z. (2009), Migracje. Wybrane zagadnienia, Wydawnictwo Uniwersytetu M.Curie-Skłodowskiej, Lublin.

Kopaliński W. (1994), Stownik wyrąón obcych i zwrotón obcojezycznych, Wiedza Powszechna, Warszawa.

Kowaleski J. (2000), Mobilność przestrzenna [in:] E. Kryńska (ed.), Mobilność zasobów pracy, IPiSS, Warszawa.

Krzyżowski J. (2010), Emigracja, imigracja, akulturacja, ,westernizacja”- naglace problemy psychiatrii transkulturowej wspótczesnego świata, „Problemy zarządzania”, vol.7, nr 3(25).

Kubitsky J. (2012), Psychologia migracji, Difin, Warszawa.

Levit P. (1998), Social Remittances: migration driven local-level forms of cultural diffusion, "International Migration Review", 32/4.

Makela K., Suutari V. (2009), Global careers: a social capital paradox, "International Journal of Human Resource Management", 20(5).

Matthewman J. (2011), The Rise of the Global Nomad: How to Manage the New Professional in Order to Gain Recovery and Maximize Future Growth, Philadelphia and London: Kogan Page.

McKenna S., Richardson J. (2007), The increasing complexity of the internationally mobile professional: issues for research and practice, "Cross Cultural Management", 14(4).

Międzynarodowa Konwencja dotycząca ochrony praw migrujących pracowników i członków ich rodzin, Zgromadzenie Ogólne Narodów Zjednoczonych, w rezolucji n. 45/158 z 18 Dec.1990.

Myers B., Pringle J.K. (2005), Self-initiated foreign experience as accelerated development: influences of gender, "Journal of World Business", 40.

OECD 2011, Glossary of statistical terms, https://stats.oecd.org/glossary/search.asp

Peltokorpi V., Froese V. (2009), Organizational expatriates and self-initiated expatriates, "International Journal of Human Resource Management", 20.

Portes A. (1999), Conclusion: towards a new world-the origins and effects of transnational activities, "Ethnic and Racial Studies", 22, 2.

Przytuła S. (2013), Flexibility - as a feature and the ability in the expatriates' qualification profile, “Edukacja dla Ekonomistów i Menedżerów”, nr 1(27).

Przytuła S. (2014 c), Ekespaci w polskich filiach-punkt widzenia polskich menedżerów [in:] S. Przytuła (ed.) Ekspatrianci w Polsce. Silne czy stabe ogniwo w zarzqdzaniu polskimi filiami? Texter, Warszawa.

Przytuła S. (2014), Zarzqdzanie kadra ekspatriantów w filiach przedsiebiorstw międzynarodowych w Polsce, CeDeWu, Warszawa.

Przytuła S., Rozkwitalska M., Chmielecki M., Sułkowski L. (2014 b), Cross-Cultural Interactions Between Expatriates and Local Managers in the Light of Positive Organizational ScholarshipPractice from Poland, "Social Sciences", No 4 (86).

Purgał-Popiela J. (2011), Sukces misji zagranicznej i jego uwarunkowania-spojrzenie z.perspektywy organizacji i ekspatrianta, „Problemy zarządzania”, vol.9, nr 4(34). 
Richardson J., McKenna S. (2003), International Experience and academic careers. What do academics have to say?, "Personnel Review", 32,6.

Richardson J., Zikic J. (2007), The darker side of an international academic career, "Career Development International", 12(2).

Sargent T. (2002), Boundaryless careers in the age of globalization: cross cultural adjustment in Japan in terms of motivation to initiate sojourn, "Disertation Abstracts International", 63 (6-B).

Saxenian A. (2005), From brain drain to brain circulation, "Studies in Comparative International Development", 40(2).

Selmer J., Lauring J. (2010), Self-initiated academic expatriates: inherent demographics and reasons to expatriate, "European Management Review", vol.7, no 3.

Stownik synonimów, http://www.slownik-synonimow.eu/ekspatriacja.

Suutari V., Brewster C. (2000), Making their own way: international experience through self-initiated foreign assignments, "Journal of World Business", 35,4.

Tharenou P. (2010), Women's self-initiated expatriation as a career option and its ethical issues, "Journal of Business Ethics", Vol.95, no 1.

Tharenou P. (2003), The initial development of receptivity to working abroad: Self-initiated international work opportunities in young graduate employees, "Journal of Occupational and Organizational Psychology", 76(4).

Thorn K. (2009), The relative importance of motives for international self-initiated mobility, "Career Development International", 14, 5.

Zięba M. (2008), Wprowadzenie [in:] M.St. Zieba (ed.), Migracje-wyzwania XXI wieku, KUL, Lublin.

Zikic J., Bonache J, Cerdin J. (2010), Crossing national boundaries: a typology of qualified immigrants' career orientations, “Journal of Organizational Behavior”, vol. 31, no 5. 